https://doi.org/10.4316/CC.2020.02.009

BOOK REVIEW

\title{
THE ROAD TO UNFREEDOM
}

\author{
Ștefan PURICI \\ Stefan cel Mare University of Suceava (Romania) \\ E-mail: stefanp@atlas.usv.ro
}

\begin{abstract}
The author reviewed the volume "The Road to Unfreedom. Russia, Europe, America", published in 2018 under the signature of the renown American researcher Timothy Snyder. The main aspects analysed by Snyder, the concepts he proposed and the interpretations formulated on the events studied are presented.
\end{abstract}

Keywords: Timothy Snyder, book review, unfreedom, Russia, Europe, America.

Rezumat: Calea către nelibertate. Autorul a întocmit o recenzie la volumul "The Road to Unfreedom. Russia, Europe, America", publicat în anul 2018 sub semnătura reputatului cercetător american Timothy Snyder. Sunt prezentate principalele aspecte analizate de Snyder, conceptele propuse de acesta și interpretările formulate pe marginea evenimentelor studiate.

"Human freedom increasingly depends on who controls what we know and, therefore, how we understand our world. It depends on what information we are able to create and disseminate: what we can share, how we can share it, and with whom we can share it".

(Rebecca MacKinnon)

Known to the Romanian public for the volumes Bloodlands. Europe between Hitler and Stalin (Humanitas Publishing House, 2012), Black Earth. The Holocaust as History and Warning (Humanitas Publishing House, 2018), On Tyranny. Twenty Lessons from the Twentieth Century (Trei Publishing House, 2018), Timothy 
Snyder has relatively recently published a new book ${ }^{1}$ on the civic and political dimension of contemporary Russian history and the implications of the internal developments of this state for Europe and America. The author of the book is a professor at Yale University specialising in Central and Eastern Europe's contemporary history. Also, he is a permanent fellow at the Institute for Human Sciences in Vienna. Timothy Snyder speaks five languages and reads ten European languages.

Over the past decade, Timothy Snyder has published six volumes ${ }^{2}$, all of which have been received with interest by specialists and the general public. The central themes of his approaches are related to the phenomena of democratic decline, political and social violence, restriction of freedoms and human rights in the 20th and 21st centuries. In collaboration with other specialists in the field,

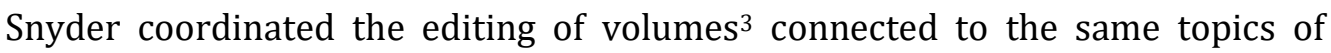
tyranny, totalitarianism, and dictatorial slippage.

Exploration of the topic of this volume began in 2017 when Timothy Snyder published the book On Tyranny: Twenty Lessons from the $20^{\text {th }}$ Century. The author highlighted the threats to freedom that are increasingly emerging in European countries and the United States. Developing this idea in the study The Road to Unfreedom, the researcher points out that the world is affected by the regression of democracy at the beginning of the 3rd millennium. While in some Eastern

1 Timothy Snyder, The Road to Unfreedom. Russia, Europe, America, New York: Tim Duggan Books, 2018, 359 p.

2 Timothy Snyder, Bloodlands: Europe Between Hitler and Stalin, New York, Basic Books, $2010,524 \mathrm{p}$.

Tony Judt with Timothy Snyder, Thinking the Twentieth Century, London, Penguin Books, 2013, 432 p.

Timothy Snyder, Black Earth. The Holocaust as History and Warning, New York: Tim Duggan Books, 2015, 462 p.

Timothy Snider, On Tyranny. Twenty Lessons from the Twentieth Century, New York: Tim Duggan Books, 2017, 128 p.

Timothy Snyder, The Road to Unfreedom. Russia, Europe, America, New York: Tim Duggan Books, 2018, 359 p.

Timothy Snider, Our Malady. Lessons in Liberty from a Hospital Diary, New York, Crown Publishing Group, 2020, 192 p.

3 Timothy Snyder and Ray Brandon, Stalin and Europe: Terror, War, Domination 19281953, New York, Oxford University Press, 2014, 326 p.

Timothy Snyder and Katherine Younger, The Balkans as Europe, 1821-1914, New York, Boydell \& Brewer 2018, 171 p. 
European states there may be a rise in authoritarianism, in Russia under Vladimir Putin an ultra-centralised and kleptocratic regime has emerged. In the West, there is a deterioration of the rule of law. Timothy Snyder notes that these processes are interdependent. In particular, the democracy crisis in the US and the EU diminishes the arsenal of levers that can obstruct the rise of an authoritarian regime in Russia. On the other hand, the Kremlin is not reluctant to use any means to strike at the West's core values and inspire distrust in the liberal system at the level of Western public opinion.

From the perspective of internal developments in Europe and the USA, the author defines two different types of organisation of society, economy and essence of regimes. On the one hand, the United States and the states of Western and Central Europe are guided by the 'politics of inevitability'. At the same time, Putin's Russia, but not only this country, is shaped by the 'politics of eternity'. According to Timothy Snyder, in the second half of the 20th Century, the USA and Western Europe were guided by the 'politics of inevitability' thinking: capitalism is superior to communism, the free market is superior to the controlled market, and politics and ideologies are subordinate to the economy. Basically, it is inevitable that, sooner or later, the nations of the world take over the Western model. This idea of predestination is categorised as <a form of forgetting $>$, a West's vulnerability. At present, the idea that the market can be the absolute answer to national problems has led to inequalities that undermine people's confidence in the system. The new leaders, ignoring or minimising the importance and role of genuine democracy, invent external threats, draw an immaculate national past, and generate false problems to distract people from their real needs. On this path of democratic involution, some European states such as Hungary and Poland have come a long way. The United States, under Donald Trump's administration, has moved in a similar direction.

According to Snyder, sliding down the slope of authoritarianism in Western democracies is the transition from the first form of forgetting, to the second: "the politics of eternity." The author considers that the latter orientation promoters try to ensure their governance neither by promises of vital projects for the society, nor by their political achievements, but by nostalgia (p. 110). These politicians build the besieged fortress's image: an innocent nation under constant threat from outside forces. In this context, eternity politicians pervert and empty national history of truth and suppress documentary facts. Instead, the people are given a past consisting of crisis, threat, and defence. At the same time, eternity politicians 
invent major problems or exaggerate existing ones, constructing goals that cannot be achieved, but which can be the pillars of the regime (p. 51).

In the case of Russia, Vladimir Putin undermined the democratic mechanism of elections. He destroyed society's trust that by resorting to the electoral instrument, the mistakes of the past can be repaired and a better future can be built. Timothy Snyder points out that the right choices generate the feeling of confidence in that options can be changed in the future and change - if desired - can occur. Thereby, "Democracy transforms human fallibility into political predictability and helps us experience time as a movement forward into a future over which we have some influence" (p. 249). Furthermore, "Democracies die when people cease to believe that voting matters" (p. 251). Restricting the nation's power to replace leaders, Vladimir Putin offered the masses the idea of a hermetic defence against external dangers, promoting the politics of eternity instead of the promise of a prosperous future (p. 273).

Timothy Snyder argues that Putin's foreign policy could be better understood if one analysed certain conservative Russian philosophers' works, especially those signed by Ivan Ilyin (1883-1954). Born and educated in Russia before World War I, with anti-Communist beliefs, he emigrated to the West in the 1920s. Teaching in Germany, Ilyin saw the "decadent" West as a threat to Russia and humanity. The philosopher promoted the idea of the "third way", considering that neither totalitarianism nor "formal" democracy is suitable for Russia. He also encouraged the "organic model" of Russian statehood, an idea shared by Putin who treats Ukraine as an inseparable part of the Russian state body (p. 112), and Russians and Ukrainians as "one people" (p. 113). Even though many of Ilyin's ideas are in line with the policy promoted by the Kremlin over the past two decades, it cannot be said, as Snyder asserts, that this philosopher's work underlies Putin's geopolitics (p. 19). Likewise, Alexander Dugin and the theory of Eurasianism are not the essential factors that were meant to shape the Kremlin's strategic thinking. Nor the assertion that the 2013 Russian Foreign Policy Concept was marked by "a series of changes corresponding to the ideas of Ilyin, the Eurasianists and their fascist traditions" (p. 99) is based on concrete data and substantiated arguments. Instead, we find that the ruling political elite is trying to capitalise on the entire conservative, ultra-Orthodox and anti-Western dowry that Russian intellectuals have produced over the past two centuries. The concepts of Ivan Ilyin or Alexander Dugin are only part of this ideational baggage.

At the same time, the development model chosen by Russia (economy controlled by authority-approved oligarchs; dependence of the budget on exports 
of raw materials; mimicking democracy; tight control by the centre over local issues, etc.) does not give Putin any chance to turn the country into a strong state and bring the Russian Federation closer to the level of development of Western Europe or the USA. Moreover, the strength and dynamics of the West pose threats (pp. 145-146) to the regime which is controlled by the Kremlin, and for these reasons, the power and influence of democratic states must be eroded. Instead of identifying solutions to the problems facing Russia, Putin prefers to export them (p. 249). Therefore, if you can show (and contribute, openly or by less visible means) that the European Union faces many problems and its unity can be broken, that American democracy is not perfect and you can bring a Russian puppet as president, that neighbouring states are free to choose their partners only within limits agreed by the Kremlin, then you can show Russian society that the rest of the world is no better than Russia. In support of his theory, Timothy Snyder provides conclusive examples. Thus, to destabilise the European Union, the Kremlin ordered the bombing of Syria, which led to the creation of large waves of migrants (p. 199); funded the political forces that promoted Brexit; provided financial and political support to extremist formations in the EU Member States (pp. 100-104). To prevent the Western model of social organisation from advancing to Russia's borders, Putin invaded Ukraine. To strike at the foundations of American democracy, the Kremlin was involved in the 2016 US elections. However, apart from a thorough analysis, the internal causes that generated the respective processes remain, the American researcher insisting on Russia's role and influence. Also, the notions of "Fascist Russia" and "Russian fascism" introduced by Snyder and often used throughout the book remain questionable and unproven.

Among the small inaccurate details - which do not change the big picture is the author's assertion that Putin's career choice in the KGB was inspired by Max Stierlitz (p. 44), the main character of the Soviet series Seventeen Moments of Spring (1973), the equivalent of James Bond in Western culture. In fact, in the mid1990s Putin himself claimed that his career choice was influenced by the story of Russian spy Conon Molody, the hero of the Soviet film Dead Season (1968). Also, the American researcher's statement according to which in the Brezhnev era the cult of Joseph Stalin was revived (p. 40) is not in accordance with the historical reality. But we agree with the author who highlights Putin's role in painting a positive image of Stalin, a picture of a strong leader and saviour of the homeland. Snyder's assertion that the American Confederate flag inspired the separatists' 
flag in Donbas and the self-proclaimed Republic of Novorossia is also erroneous. (p. 148).

Certainly, other aspects can be identified that can generate historiographical debates, but the American researcher's work is as exciting as it is easy to assimilate. According to Timothy Snyder, his book diagnoses system vulnerabilities and is part of the treatment that should be applied to cure our political infirmity. 